\title{
RAGAM LIKEN BERDASARKAN KETINGGIAN DATARAN SEBAGAI BIOINDIKATOR KUALITAS EKOSISTEM DI CAGAR ALAM RAWA DANAU SERANG BANTEN
}

\section{Lichen Diversity Based on Altitude in Rawa Danau Nature Reserve Serang Banten as Environmental Bioindicator}

\section{Rida Oktorida Khastini, Indah Juwitasari, Siti Sulasanah}

Pendidikan Biologi, Fakultas Keguruan dan Ilmu Pendidikan, Universitas Sultan Ageng Tirtayasa, Serang, Indonesia email: rida.khastini@untirta.ac.id

\begin{abstract}
Lichen is a symbiotic organism, made up of two or more different organisms living together. Lichen biodiversity may provide an excellent system in bio-monitoring of the ecosystem health of nature reserve areas such as Rawa Danau in Banten Province, Indonesia. The study on lichen diversity was conducted on Rawa Danau based on altitude using transect based plot in three main habitats based on altitude e.g. $90 \mathrm{mbsl}, 100-130$ mbsl, $130-160 \mathrm{mbsl}, 160-187 \mathrm{mbsl}$. A total 63 specimens were collected from these four areas which resulted in the occurrence of 19 species of lichens belonging to 17 genera and 13 families. Shannon-Winner's diversity index from 1.494 to 2.6678. The variation in species composition was related to the environmental habitat variables and lichens demonstrated a condition of environmental alteration.
\end{abstract}

Key Words: bioindicator; lichen diversity; altitude; rawa danau

\section{PENDAHULUAN}

Indonesia merupakan suatu kepulauan dengan jumlah 34 provinsi yang mempunyai ragam kekayaan sumber daya alam yang terdapat di perairan, hutan, dan pegunungan. Berdasarkan penelitian Dewi et al. (2017) menyatakan bahwa kekayaan sumber daya alam hayati dimanfaatkan oleh masyarakat Indonesia sebesar $81 \%$ namun dalam pemanfaatannya belum dilakukan secara 
optimal, agar potensi tersebut tetap lestari, dalam pemanfaatan perlu dilakukan upaya konservasi berupa cagar alam.

Salah satu cagar alam di Provinsi Banten yang dilindungi adalah rawa danau. Rawa danau merupakan suatu rawa pegunungan dataran rendah tropis yang bertempat di Kecamatan Mancak, Kabupaten Serang, Provinsi Banten pada ketinggian 90 m diatas permukaan air laut yang mengandung air tawar yang signifikan dengan suhu lingkungan yang asri. Menurut penelitian Rangga (2009), sebagian dari wilayah cagar alam rawa danau berupa dataran rawa dan perairan danau, kecuali di bagian sebelah utara terdapat sebuah bukit kecil dengan luas kurang lebih $8 \mathrm{Ha}$ dengan ketinggian 90-225 $\mathrm{m}$ dpl (di atas permukaan laut), yaitu merupakan Gunung Jamungkal. Priyanto \& Titiresmi (2006) mengemukakan bahwa rawa danau diyakini sebagai sebuah rawa.

Air tawar pegunungan terakhir yang ada di pulau Jawa karena itu secara ekologi kelestarian rawa danau sangat penting. Kelestarian rawa danau dapat berubah seiring dengan berjalannya waktu dan banyaknya aktivitas manusia untuk memenuhi kebutuhan, sehingga mengganggu kelangsungan hidup flora dan fauna yang terdapat di dalamnya. Oleh karena itu diperlukan suatu cara untuk memantau kondisi lingkungan agar lebih mudah diketahui baik buruknya suatu kondisi lingkungan tersebut, salah satunya adalah dengan memanfaatkan liken. Menurut Wahid et al. (2011) liken telah digunakan sebagai indikator kualitas lingkungan sejak tahun 1866.

Nimis et al. (2002) menambahkan bahwa pada lingkungan terrestrial liken telah banyak digunakan untuk memonitor berbagai jenis polutan. Liken merupakan suatu organisme hasil dari simbiosis alga dan fungi sehingga dalam siklus hidupnya saling menguntungkan. Liken juga mempunyai keunikan yaitu dapat hidup dimanapun, baik di batu, pohon, dan tanah. Hal tersebut diperkuat oleh Campbell et al. (2012) bahwa liken adalah suatu asosiasi simbiotik dari berjuta-juta mikroorganisme fotosintetik yang disatukan dalam jaringan hifa fungi. Pasangan fotosintetiknya umumnya adalah alga hijau uniseluler atau berfilamen atau cyanobacteria. Penyatuan fungi dan alga adalah sedemikian sempurnanya sehingga liken tersebut sesungguhnya diberikan nama genus dan spesies seolah-olah organisme tunggal. Informasi 
mengenai liken sebagai indikator lingkungan di Indonesia masih minim karena itu perlu dilakukan penelitian terkait keanekaragaman liken dan fungsinya sebagai bioindikator lingkungan sebagai dasar untuk penentuan kebijakan terkait dengan pelestarian lingkungan. Tujuan dari penelitian ini adalah untuk mengetahui ragam liken sebagai bioindikator kualitas lingkungan CA. Rawa Danau.

\section{METODE PENELITIAN}

\section{a. Waktu dan Tempat Penelitian}

Pengambilan data sampel akan dilakukan pada bulan Februari- September 2018 yang berlokasi di cagar alam Rawa Danau Mancak Serang Banten yang memiliki titik koordinat pada $6^{\circ} 8^{\prime}-6^{\circ} 11^{\prime}$ LS dan $105^{\circ} 56^{\prime}-106^{\circ} 04^{\prime}$ BT. Identifikasi keanekaragaman liken dilakukan di Laboratorium Biologi Fakultas Keguruan dan Ilmu Pendidikan Universitas Sultan Ageng Tirtayasa.

\section{b. Alat dan Bahan Penelitian}

Alat yang digunakan untuk pengambilan data liken pada penelitian ini adalah $\mathrm{pH}$ meter, meteran, termohigrometer, GPS, altimeter, lux meter, pita meter, mikroskop cahaya "Leica", lup, gelas objek, gelas penutup, timbangan analitik, alat tulis, wadah untuk sampel liken, papan jalan, pisau, patok dan kamera DSLR "Nikon". Bahan-bahan yang digunakan untuk pengambilan sampel liken pada penelitian ini adalah tali rapia, tali tambang, kertas label, spidol transparansi, plastik transparan ukuran F4, Laktofenol analin blue, $\mathrm{KOH} 10 \%$, Iodium, $\mathrm{Ca}(\mathrm{OCl}) 2$ dan plastik zip-lock.

\section{c. Survei Lokasi Penelitian}

Survei dilakukan untuk mengetahui kondisi rawa danau serta menentukan lokasi pengambilan sampel yang terdapat liken. Penentuan lokasi menggunakan metode purposive sampling berdasarkan keadaan geografis yang berbeda. Lokasi 
penelitian dibagi kedalam empat stasiun berdasarkan ketinggian dataran, yaitu $90 \mathrm{mdpl}, 100-130 \mathrm{mdpl}, 130-160 \mathrm{mdpl}, 160-187$ mdpl.

\section{d. Pengambilan Sampel}

Pengambilan sampel liken pada stasiun 1 menggunakan metode jelajah sedangkan pada stasiun 2, 3, dan 4 menggunakan metode transek garis. Pembuatan line transek dibuat garis lurus dengan ukuran $100 \mathrm{~m}$ dan di dalamnya dibuat plot-plot dengan masing-masing ukuran plot $5 \mathrm{~m} \times 5 \mathrm{~m}$. Setiap stasiun memuat 3 plot, namun pada stasiun 1 dengan ketinggian dataran $90 \mathrm{mdpl}$ tidak dibuat plot melainkan jelajah dengan jarak $150 \mathrm{~m}$, karena terdapat di rawa (Gambar 1).

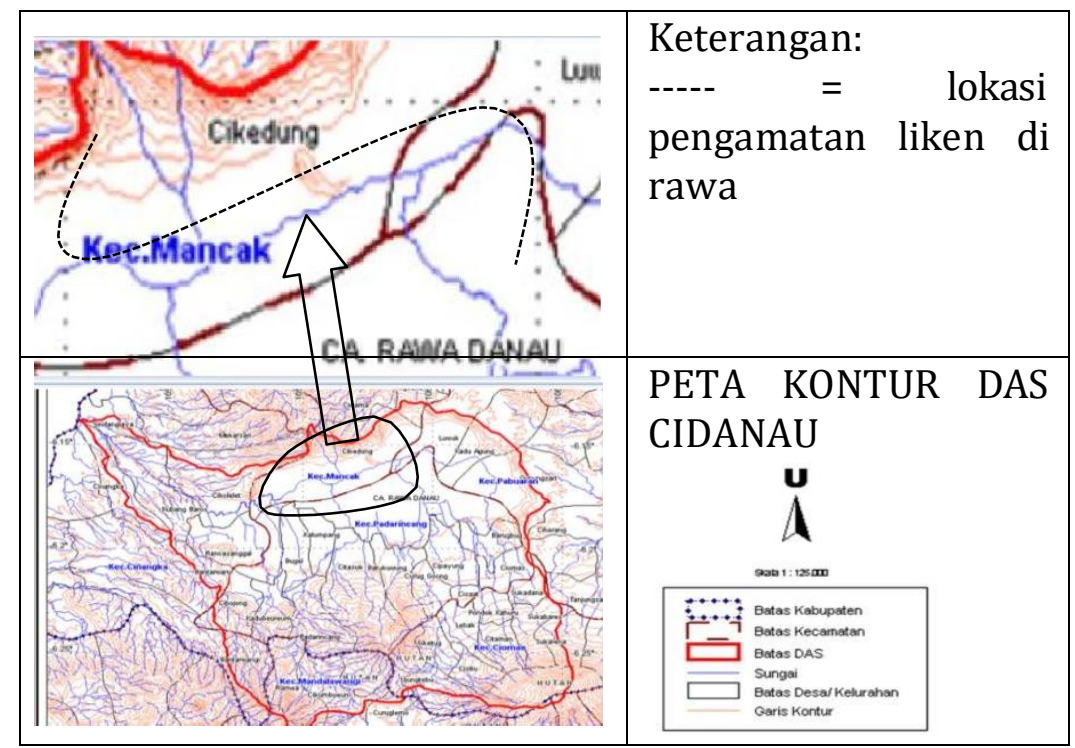

Gambar 1. Ilustrasi metode jelajah di stasiun 1

Stasiun 2 dengan ketinggian dataran 100-130 mdpl dibuat 3 plot yang dibuat secara zig-zag dan setiap plot terdapat jarak 25m. Statsiun 3 dengan ketinggian dataran 130-160 mdpl, dibuat 3 plot yang dibuat secara zig-zag dan setiap plot terdapat jarak 25m. Stasiun 4 dengan ketinggian dataran 160-187 mdpl, dibuat 3 plot yang dibuat secara zig-zag dan setiap plot terdapat jarak 25m (Gambar 2). 


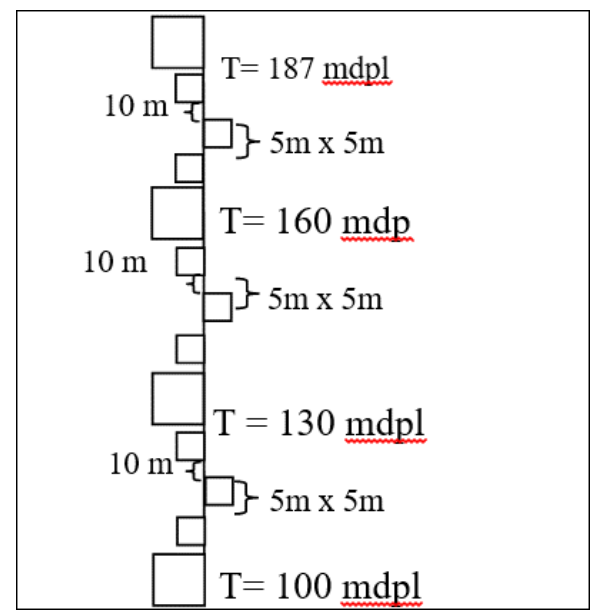

Gambar 2. Ilustrasi peletakan plot pengambilan sampel liken

Pengamatan dan pengambilan sampel dilakukan dengan cara mengambil liken yang terdapat di setiap substrat yaitu pohon, batu dan tanah. Sampel liken dipisahkan dari substratnya dengan menggunakan pisau dan dimasukkan ke dalam plastik dan diberi identitas (Trisusanti 2003).

Kegiatan identifikasi di laboratorium dilakukan secara fisik dengan mengamati struktur anatomi talus liken dengan menggunakan larutan Laktofenil analin blue $1 \%$ dengan bantuan mikroskop majemuk, mikroskop stereo dan lup, sedangkan secara kimiawi dilakukan reaksi uji warna talus menggunakan larutan $\mathrm{KOH} 10 \%$, Iodium dan Ca (OCl)2. Pengukuran berat tutupan talus liken menggunakan timbangan analitik. Hasil identifikasi dicocokkan dengan kunci identifikasi liken (Sipman 2003).

\section{e. Pengukuran Faktor Lingkungan}

Faktor-faktor lingkungan pada setiap plot diukur sebagai data pendukung pada penelitian ini. Faktor lingkungan yang diukur yaitu suhu dan kelembapan udara, derajat keasaman $(\mathrm{pH})$, intensitas cahaya dan jenis substrat. Suhu dan kelembapan akan diukur menggunakan termohigrometer udara. Termohigrometer udara digantungkan pada setiap plot 
kemudian didiamkan beberapa saat setelah itu dilihat nilai kelembapan (\%) dan nilai suhu (0C) pada layar. Derajat keasaman $(\mathrm{pH})$ diukur menggunakan $\mathrm{pH}$ meter. Soil tester dimasukkan kedalam tanah/air rawa dan kemudian akan muncul nilai $\mathrm{pH}$ tanah/air rawa tersebut. Intensitas cahaya diukur menggunakan luxmeter. Sensor cahaya diarahkan ke daerah yang akan diukur besar intensitas cahaya kemudian nilai intensitas cahaya akan muncul. Jenis substrat akan di amati melalui pengamatan jenis substrat. Selain itu, titik koordinat disetiap stasiun diukur menggunakan aplikasi GPS.

\section{f. Indeks keanekaragaman jenis (H')}

Keanekaragaman jenis liken yang terdapat pada tiga lokasi pengamatan ditentukan dengan menggunakan indeks keanekaragaman Shannon-Wiener $\left(\mathrm{H}^{\prime}\right)$ menurut Bordeaux (2015) dengan rumus:

$$
\mathbf{H}^{\prime}=-\mathbf{E P i} \ln \mathbf{P i} ; \mathbf{p i}=\underset{N}{\mu i}
$$

Keterangan:

$\mathrm{H}^{\prime}$ = Indeks keanekaragaman Shannon-Wiener

$\mathrm{ni}=$ Jumlah individu setiap jenis

$\mathrm{N}=$ Jumlah individu seluruh jenis

$\mathrm{Pi}=$ Kelimpahan setiap jenis

Selanjutnya nilai $\mathrm{H}^{\prime}$ yang diperoleh dicocokan dengan kriteria indeks keanekaragaman Shannon-Wienner pada Tabel 1.

Tabel 1.

Kriteria indeks Shannon-Wiener

\begin{tabular}{lll}
\hline No & Nilai H' & \multicolumn{1}{c}{ Kriteria } \\
\hline 1 & $\mathrm{H}^{\prime} \leq 1$ & $\begin{array}{l}\text { Keanekaragaman rendah, jumlah individu tidak } \\
\text { seragam, ada spesies yang dominan. }\end{array}$ \\
2 & $1 \leq \mathrm{H}^{\prime} \leq 3$ & $\begin{array}{l}\text { Keanekaragaman sedang, jumlah individu hampir } \\
\text { seragam, ada beberapa spesies yang dominan. } \\
\text { Keanekaragaman tinggi, jumlah individu seragam, } \\
\text { tidak ada spesies yang dominan. }\end{array}$ \\
\hline
\end{tabular}




\section{g. Penentuan Kualitas Ekosistem Berdasarkan Indeks Keanekaragaman}

Untuk menentukan kualitas ekosistem berdasarkan indikator indeks keanekaragaman, dapat mengikuti kriteria Shanon- Wienner yang dapat dilihat pada Tabel 2. Kriteria menurut Attanayaka \& Wijeyaratne (2013) dengan modifikasi sebagai berikut:

Tabel 2.

Kriteria kualitas ekosistem berdasarkan Indeks ShannonWienner

\begin{tabular}{cll}
\hline No & \multicolumn{1}{c}{ Nilai H' } & \multicolumn{1}{c}{ Kualitas Ekosistem } \\
\hline 1 & $\mathrm{H}^{\prime} 0,80-0,89$ & Kualitas ekosistem buruk \\
2 & $\mathrm{H}^{\prime} 0,90-0,99$ & Kualitas ekosistem sedang \\
3 & $\mathrm{H}^{\prime} 1,00-1,09$ & Kualitas ekosistem baik \\
4 & $\mathrm{H}^{\prime} \geq 1,10$ & Kualitas ekosistem sangat baik \\
\hline
\end{tabular}

\section{HASIL DAN PEMBAHASAN Kondisi Umum di Lokasi Penelitian}

Cagar Alam Rawa Danau terletak di Desa Cikedung, Kecamatan Mancak, Kabupaten Serang-Banten. Secara geografis Cagar Alam Rawa Danau titik koordinat pada $6^{\circ} 8^{\prime}-6^{\circ} 11^{\prime}$ LS dan 10556'- 106 04' BT Cagar Alam Rawa Danau terbagi wilayah berupa dataran rawa dan bukit kecil yaitu Gunung Jamungkal memiliki luas kurang lebih $8 \mathrm{Ha}$, dengan ketinggian 187m di atas permukaan laut (dpl). Rawa Danau ditetapkan sebagai Cagar Alam dengan luas 3.542,70 Ha (BKKSDA, 2016).

Lokasi penelitian dibuat menjadi 4 stasiun berdasarkan ketinggian dataran, yaitu stasiun 1 (90 mdpl), stasiun 2 (100-130 mdpl), stasiun 3 (130-160 mdpl) dan stasiun 4 (160-187 mdpl) (Gambar 2). 


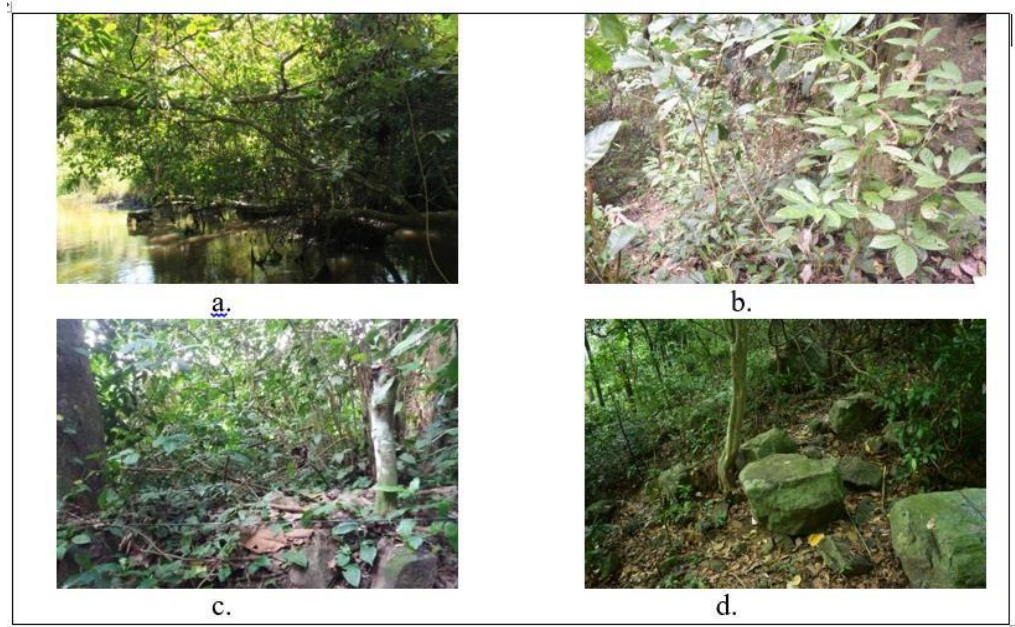

Gambar 3. Lokasi pengambilan sampel pada ketinggian a. 90 mdpl, b. 100130 mdpl, c. 130-160 mdpl dan d. 160-180 mdpl.

Pada stasiun 1 (90 mdpl) merupakan stasiun berupa dataran rawa dengan titik koordinat $6^{\circ} 9^{\prime} 58.669$ LS dan $105^{\circ} 57^{\prime} 34.664$ BT. Stasiun 1 didominasi oleh vegetasi pohon Jajawai (Ficus microcarpa) dan pohon Gempol (Nandea cordatus). Stasiun 2 (100130 mdpl) merupakan bagian kaki Gunung Jamungkal dengan titik koordinat $6^{\circ} 9^{\prime} 24.836 \mathrm{LS}$ dan $105^{\circ}$ 58' 35.699 BT. Pada stasiun 2 didominasi oleh vegetasi hutan pohon Ki toke (Albizzia lebbeck), pohon Melinjo (Gnetum gnemon) dan pohon Buni (Antidesma bunius). Stasiun 3 (130-160 mdpl) merupakan bagian tengah Gunung Jamungkal dengan titik koordinat koordinat $6^{\circ} 9^{\prime} 27.296$ LS dan $105^{\circ} 58^{\prime} 36.156$ BT. Pada stasiun 3 didominasi oleh vegetasi hutan pohon Langkap (Arenga obtusifolia), pohon Mara (Macaranga tanarius) dan pohon Ki mokla (Myristica guatterifolia) dapat dilihat pada (Lampiran 3).

Stasiun 4 (160-187 mdpl) merupakan bagian puncak Gunung Jamungkal dengan titik koordinat $6^{\circ} 9^{\prime} 31.255$ LS dan $105^{\circ} 58^{\prime}$ 38.802 BT. Pada stasiun 4 didominasi oleh vegetasi hutan pohon Huru (Elaecocarpus Sp.), pohon Teureup (Arthocarpus elasticus), pohon Pinangsih (Villebrunea rubescens), pohon Ki toke (Albizzia lebbeck), pohon Langkap (Arenga obtusifolia Bl.), pohon Mara (Macaranga tanarius). 


\section{Komposisi Jenis Liken}

Liken adalah asosiasi simbiotik dari fungi yaitu Ascomycetes, dan terkadang berasal dari Basidiomycetes atau Phycomycetes dan alga yaitu Cyanobacteriae atau Chlorophyceae. Alga merupakan bagian yang mengandung nutrisi yang memuat krolofil, sementara fungi berfungsi memberikan alga air dan mineral (Bordeaux, 2015).

Berdasarkan hasil pengamatan yang telah dilakukan secara makroskopis dan mikroskopis, jenis liken yang diperoleh dari empat stasiun di Cagar Alam Rawa Danau dapat teridentifikasi sebanyak 19 jenis. Hasil pengamatan menunjukkan bahwa pada stasiun 1 diperoleh liken sebanyak 14 jenis, setelah diidentifikasi terdapat 8 genus dan 6 spesies. Pada stasiun 2 diperoleh liken sebanyak 6 jenis, setelah diientifikasi terdapat 4 genus dan 2 spesies. Pada stasiun 3 diperoleh liken sebanyak 6 jenis, setelah diidentifikasi terdapat 5 genus dan 1 spesies. Pada stasiun 4 diperoleh liken sebanyak 9 jenis setelah diientifikasi terdapat 6 genus dan 3 spesies data tersebut dapat dilihat pada Tabel 3.

Tabel 3

Komposisi jenis liken pada stasiun 1, 2, 3 dan 4

\begin{tabular}{|c|c|c|c|c|c|c|c|c|c|c|c|}
\hline \multirow[b]{2}{*}{ No } & \multirow[b]{2}{*}{ Jenis liken } & \multirow[b]{2}{*}{ Family } & \multirow{2}{*}{$\begin{array}{l}\text { Mo } \\
\text { r } \\
\text { folo } \\
\text { gi }\end{array}$} & \multicolumn{4}{|c|}{ Hasil uji warna } & \multicolumn{4}{|c|}{ Lokasi pengamatan } \\
\hline & & & & I & $\mathbf{K}$ & C & KC & $\begin{array}{l}\text { St } \\
1\end{array}$ & $\begin{array}{l}\text { St } \\
2\end{array}$ & $\begin{array}{l}\text { St } \\
3\end{array}$ & $\begin{array}{l}S \\
4\end{array}$ \\
\hline 1. & Buellia sp. & Caliciaceae & $\mathrm{C}$ & - & + & + & + & $\sqrt{ }$ & - & - & - \\
\hline 2. & Dirinaria sp. & Caliciaceae & $\mathrm{F}$ & - & + & + & + & $\sqrt{ }$ & - & - & - \\
\hline 3. & $\begin{array}{l}\text { Hafelli } \\
\text { a } \\
\text { levieri }\end{array}$ & Physciaceae & $\mathrm{C}$ & - & + & + & + & $\sqrt{ }$ & $\sqrt{ }$ & $\sqrt{ }$ & $\sqrt{ }$ \\
\hline 4. & Arthonia sp. & Arthoniaceae & $\mathrm{C}$ & - & + & + & + & $\sqrt{ }$ & - & - & - \\
\hline 5. & $\begin{array}{l}\text { Cryptotheci } \\
\text { a effusa }\end{array}$ & & $\mathrm{C}$ & - & + & + & + & - & $\sqrt{ }$ & - & $\sqrt{ }$ \\
\hline 6. & $\begin{array}{l}\text { Cryptothecia } \\
\text { sp. }\end{array}$ & Arthoniaceae & $\mathrm{C}$ & - & + & + & + & - & - & $\sqrt{ }$ & $\sqrt{ }$ \\
\hline 7. & $\begin{array}{l}\text { Cryptothecia } \\
\text { striata }\end{array}$ & & $\mathrm{C}$ & - & + & + & + & - & - & - & $\sqrt{ }$ \\
\hline
\end{tabular}




\begin{tabular}{|c|c|c|c|c|c|c|c|c|c|c|c|}
\hline \multirow[b]{2}{*}{ No } & \multirow[b]{2}{*}{ Jenis Liken } & \multirow[b]{2}{*}{ Family } & \multirow[b]{2}{*}{$\begin{array}{l}\text { Morf } \\
\text { ologi }\end{array}$} & \multicolumn{4}{|c|}{ Hasil uji warna } & \multicolumn{4}{|c|}{ Lokasi pengamatan } \\
\hline & & & & I & $\mathbf{K}$ & $\mathbf{C}$ & KC & $\begin{array}{l}\text { St } \\
1\end{array}$ & $\begin{array}{l}\text { St } \\
2\end{array}$ & $\begin{array}{l}\text { St } \\
3\end{array}$ & $\begin{array}{l}S \\
4\end{array}$ \\
\hline 8. & Graphis sp. & Graphidaceae & $\mathrm{C}$ & + & + & + & + & $\sqrt{ }$ & $\sqrt{ }$ & $\sqrt{ }$ & $\sqrt{ }$ \\
\hline 9. & $\begin{array}{l}\text { Phyllopsora } \\
\text { sp. }\end{array}$ & Ramalinaceae & $\mathrm{C}$ & - & + & + & + & $\sqrt{ }$ & - & $\sqrt{ }$ & - \\
\hline 10. & $\begin{array}{l}\text { Flavoparmeli } \\
\text { a caperata }\end{array}$ & & $\mathrm{F}$ & - & + & + & + & $\sqrt{ }$ & - & - & - \\
\hline 11. & $\begin{array}{l}\text { Myelochroa } \\
\text { obsessa }\end{array}$ & Parmeliaceae & $\mathrm{F}$ & - & + & + & + & $\sqrt{ }$ & - & - & - \\
\hline 12. & Anzia sp. & & $\mathrm{F}$ & + & + & + & + & $\sqrt{ }$ & - & - & - \\
\hline 13. & $\begin{array}{l}\text { Hydropunctar } \\
\text { ia maura }\end{array}$ & Verrucariaceae & $\mathrm{C}$ & - & + & + & + & $\sqrt{ }$ & - & - & - \\
\hline 14. & Porina distans & Porinaceae & $\mathrm{C}$ & - & + & + & + & $\sqrt{ }$ & - & - & - \\
\hline 15. & Lepraria sp. & Stereocaulaceae & $\mathrm{C}$ & + & + & + & + & $\sqrt{ }$ & - & - & $\sqrt{ }$ \\
\hline 16. & $\begin{array}{l}\text { Chrysotrhix } \\
\text { xanthine }\end{array}$ & Chrysothricaceae & $\mathrm{C}$ & + & + & + & + & $\sqrt{ }$ & - & - & - \\
\hline 17. & Caloplaca sp. & Teloschistaceae & $\mathrm{C}$ & - & + & + & + & $\sqrt{ }$ & - & - & - \\
\hline 18. & Pertusaria sp. & Pertusariaceae & $\mathrm{C}$ & + & + & - & + & - & $\sqrt{ }$ & $\sqrt{ }$ & - \\
\hline 19. & $\begin{array}{l}\text { Musaespora } \\
\text { sp. }\end{array}$ & Monoblastiaceae & $\mathrm{C}$ & + & + & + & + & - & $\sqrt{ }$ & $\sqrt{ }$ & $\sqrt{ }$ \\
\hline
\end{tabular}

Berdasarkan data tersebut morfologi liken yang terdapat di Cagar Alam Rawa Danau di 4 stasiun didominasi oleh tipe talus crustose (talus sangat melekat erat pada substratnya dan memiliki lobus yang kecil memusat) yaitu sebanyak 15 jenis dan foliose (memiliki karakteristik daunnya seperti lobus). Morfologi talus liken dapat dilihat pada Gambar 3. 


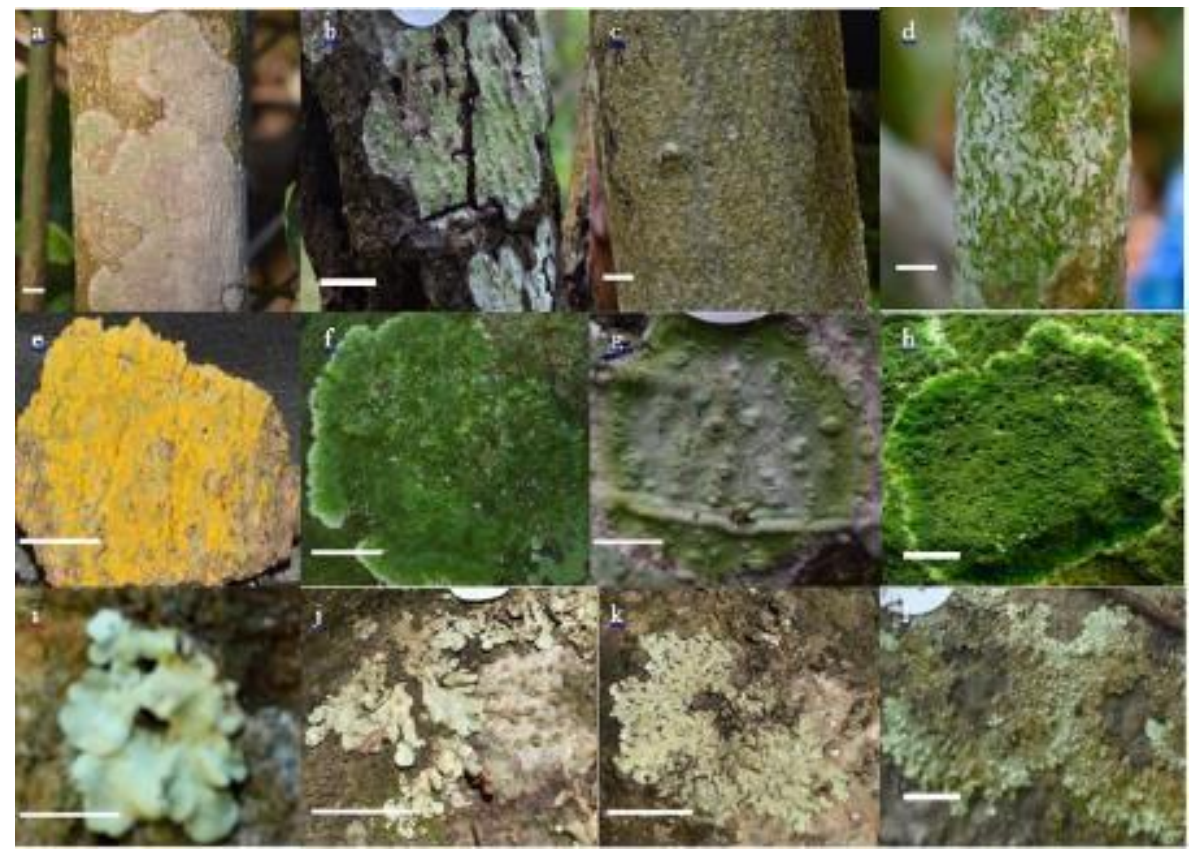

Gambar 4. Morfologi Talus Liken di CA. Rawa Danau. a-d liken tipe crustose pada substrat batang pohon, e-h iken tipe crustose pada substrat batuan, i-l iken tipe foliose pada substrat batang pohon

Rasyidah (2018), mengemukakan bahwa tipe talus crustose merupakan tipe talus yang paling resisten dibandingkan dengan tipe talus lainnya. Hal tersebut terjadi karena liken dengan tipe morfologi talus crustose terlindung dari potensi kehilangan air dengan bertahan pada substratnya, mengingat tipe ini memiliki sifat melekat erat pada substratnya dan tipe jaringan talus homoiomerous, yaitu keadaan phycobiont (alga) berada di sekitar hifa. Sedangkan liken foliose dapat ditemukan hanya pada stasiun 1 (90 mdpl) dengan jumlah 4 jenis dikarenakan kondisi lingkungan dan substrat yang ditempati sangat cocok untuk pertumbuhan liken tersebut. Hal ini sesuai dengan pendapat Yazici \& Aslan (2006) bahwa daerah yang memiliki cukup banyak liken foliose mengindikasikan kondisi yang baik untuk pertumbuhan liken. 


\section{Faktor-faktor Lingkungan di CA Rawa Danau}

Faktor-faktor yang dapat mempengaruhi suatu pertumbuhan liken yaitu suhu, kelembaban udara, intensitas cahaya dan $\mathrm{pH}$ Berdasarkan hasil observasi suhu paling tertinggi yaitu pada stasiun $3(130-160 \mathrm{mdpl})$ dengan suhu $32.3^{\circ} \mathrm{C}$ sedangkan terendah terdapat pada ketinggian $90 \mathrm{mdpl}$ dan 160 187 mdpl dengan suhu $29.5^{\circ} \mathrm{C}$, kemudian disusul oleh stasiun 4 (160-187 mdpl) dengan suhu $29^{\circ} \mathrm{C}$. Jenis liken yang ditemukan pada stasiun 3 lebih rendah dibandingkan dengan stasiun 1 dan stasiun 4, karena suhu mempunyai peran yang penting untuk pertumbuhan liken untuk membantu metabolism.

Nursal et al. (2014), mengemukakan bahwa suhu merupakan faktor yang penting bagi tumbuhan, karena suhu menentukan kecepatan reaksi dan kegiatan kimiawi dalam proses kehidupan. Suhu juga merupakan faktor iklim yang ikut mendukung keberadaan suatu vegetasi, karena suhu berpengaruh pada proses metabolisme. Kelembapan udara tertinggi terdapat pada stasiun 1 (90 mdpl) dengan kelembapan udara 92\%, kemudian disusul oleh stasiun 3 (130-160 mdpl) dengan kelembapan udara $91 \%$ sedangkan terendah terdapat pada stasiun 2 (100-130 mdpl) dengan kelembapan 80\%. Jenis liken yang ditemukan pada stasiun 2 lebih rendah dibandingkan dengan stasiun 1, karena kelembapan udara yang tinggi dapat lebih cepat dalam membantu proses pertumbuhan liken, hal tersebut diperkuat oleh Sipman \& Haris (2007), bahwa liken tumbuh dengan baik di suhu dingin, kelembaban yang tinggi dan sedikit cahaya matahari.

Intensitas cahaya tertinggi terdapat pada stasiun $1(90$ mdpl) dengan intensitas cahaya 199.33x10, kemudian disusul oleh stasiun 3 (130-160 mdpl) dengan intensitas cahaya 183.9x10 sedangkan terendah terdapat pada satsiun 2 (100-130 mdpl) dengan intensitas cahaya $162 \times 10$. Jenis liken yang ditemukan pada stasiun 1 lebih tinggi dibandingkan dengan stasiun 2, meskipun intensitas cahaya lebih tinggi pada stasiun 1 . Hal tersebut dapat terjadi karena faktor lingkungan saling mempengaruhi satu sama 
lain, sehingga pada stasiun 1 jenis liken lebih beragam karena suhu dan kelembapan udara pada stasiun 1 lebih baik untuk pertumbuhan liken, sebagaimana menurut Sipman dan Haris (2007) bahwa liken tumbuh dengan baik di suhu dingin, kelembaban yang tinggi dan sedikit cahaya matahari.

\section{Keanekaragaman Jenis Liken Berdasarkan Ketinggian Dataran sesuai dengan Faktor Lingkungan di Cagar Alam Rawa Danau}

Faktor seperti suhu, kelembapan udara, intensitas cahaya dan $\mathrm{pH}$ sangat membantu bagi keanekaragaman liken di suatu daerah. Substrat yang terdapat di suatu daerah pun ikut berperan untuk keanekaragaman liken. Keanekaragaman liken di Cagar Alam Rawa Danau paling tertinggi keanekaragamannya yaitu pada stasiun 1 (90 mdpl) dengan $\mathrm{H}^{\prime}$ 2.6678, kemudian disusul pada stasiun 4 (160-187 mdpl) dengan $\mathrm{H}^{\prime} 1.9567$ sedangkan keanekaragaman liken terendah terdapat pada stasiun 2 (ketinggian 100-130 mdpl) dengan $\mathrm{H}^{\prime} 1.494$.

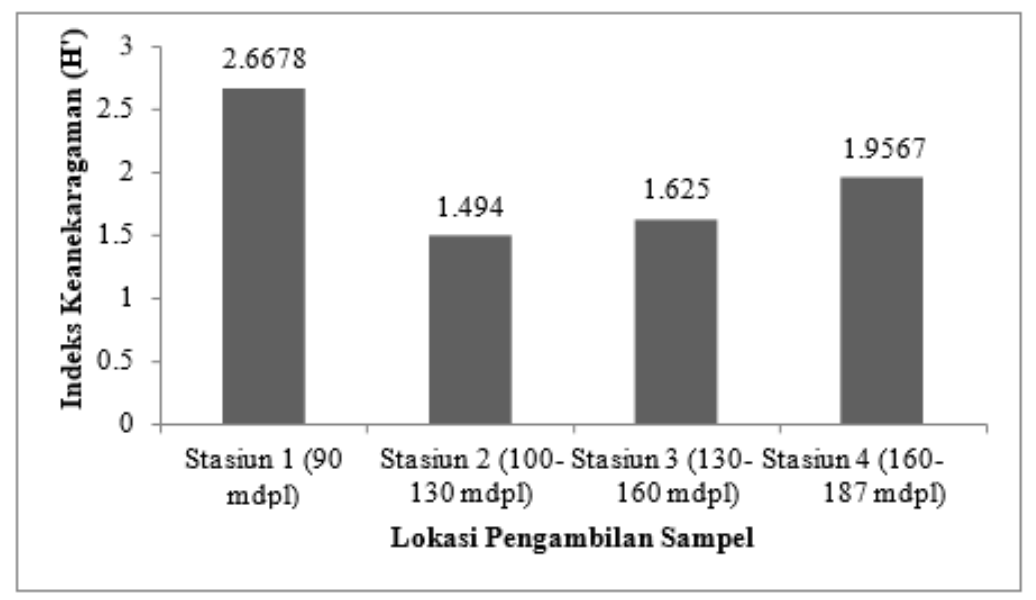

Gambar 5. Indeks keanekaragaman liken di Cagar Alam Rawa Danau 


\section{KESIMPULAN}

Berdasarkan hasil penelitian yang telah dilakukan dapat disimpulkan bahwa keanekaragaman liken di Cagar Alam Rawa Danau sebanyak 63 spesimen diperoleh dari empat stasiun yang terdiri dari 19 spesies, 17 genus, dan 13 famili. Keanekaragaman liken paling tinggi yaitu pada stasiun 1 (90 mdpl), sedangkan terendah terdapat pada stasiun 2 (100-130 mdpl). Indeks keanekaragaman liken dari yang terendah hingga tertinggi mecapai $\mathrm{H}^{\prime}$ 1.494-H' 2.667 yang artinya kriteria tersebut disesuaikan dengan indeks Shannon-Wienner bahwa $H^{\prime} \geq 1,10$ maka keanekaragaman liken yang berada di Cagar Alam Rawa Danau tergolong keanekaragaman liken sangat tinggi. Kondisi lingkungan di Cagar Alam Rawa Danau terkini dapat dilihat dari respon liken sebagai bioindikator berdasarkan indeks kriteria kualitas ekosistem berdasarkan Indeks Shannon-Wienner bahwa kondisi lingkungan di Cagar Alam Rawa Danau termasuk kedalam kriteria kualitas ekosistem sangat baik.

\section{UCAPAN TERIMA KASIH}

Ucapan terima kasih ditujukan pada Nagao Environmental Foundation (NEF) Jepang yang telah mendanai penelitian ini dan masyarakat di CA. Rawa Danau yang telah membantu dalam pengambilan data.

\section{DAFTAR PUSTAKA}

Attanayaka, A.N.P.M \& Wijeyaratne, S.C. (2013). Corticolous lichen diversity, a potential indicator for monitoring air pollution in tropics. J. Natn. Sci. Foundation Sri Lanka 41(2):131--140.

Bordeaux, C.Z. (2015). Keanekaragaman Lumut Kerak Sebagai Bioindikator Kualitas Udara di Kebun Raya Cibodas, Kebun Raya Bogor dan Ecopark-Lipi Cibinong [Skripsi]. Institut Pertanian Bogor. 
Campbell, N.A., J.B. Reece \& L.G. Mitchell. (2012). Biologi Jilid 2 Edisi ke delapan. Erlangga, Bogor: $\mathrm{x}+404 \mathrm{hlm}$.

Dewi, E.C., Sunarminto, T \& Arief, H. (2017). Nilai Ekonomi Pemanfaatan Sumber Daya Alam Hayati Taman Nasional Baluran Oleh Masyarakat Desa Wonorejo Kabupaten Situbondo Jawa Timur . Media Konservasi 22(3): 277--285.

Nursal., Surwono \& Sirait, I.N. (2014). Karakteristik Komposisi dan Stratifikasi Vegetasi Strata Pohon Komunitas Ripariandi Kawasan Hutan Wisata Rimbo Tujuh Danau Kabupaten Kampar Provinsi Riau. Jurnal Biogenesis 9(2): 1--8.

Priyanto, B \& Titiresmi. (2016). Beberapa Aspek Pengelolaan Cagar Alam Rawa Danau Sebagai Sumber Air Baku. J. Tek. Ling. PTLBPPT. 7(3): 277--283.

Rangga, A.D. (2009). Pengaruh Kenaikan Suhu Terhadap Karakteristik Vegetasi di Cagar Alam Rawa Danau, Banten [Skripsi]. Depok: Universitas Indonesia

Rasyidah. (2018). Kelimpahan Lumut Kerak (lichens) sebagai Bioindikator Kualitas Udara di Kawasan Perkotaan. Klorofil 1(2): 88--92.

Sipman H. (2003). Key to the lichen genera of Bogor, Cibodas and Singapore. Tersedia pada http://www.archive. bgbm.org/sipman/keys/ Javagenera.htm

Sipman H.J.M. \& Harris R.C. (2007). Biotrop Fourth Regional Training Course On Biodiversity Conservation Of Bryophytes And Lichen, Seameo Biotrop, Bogor, Indonesia. Biotrop courier. 10(2): 1--12.

Trisusanti, D. (2003). Inventarisasi Liken Krustos Lirella Asal Jawa Barat dan Pengenalan Bentuk Kristalnya [Skripsi]. Bogor: Institut Pertanian Bogor.

Wahid, M., Din, L., Zakaria, Z., Latip, J., Lihan, T., Jemain, A.A \& Samsudin, F. (2011). Measuring air quality using lichen 
Khastini, R.O., Juwitasari, I., dan Sulasanah

mapping at Universiti Kebangsaan Malaysia (UKM) Campus. Procedia-Social and Behavioral Sciences 59: 635-443

Yazici, K \& Aslan, A. (2006). Distribution of Epiphytic Lichens and Air Pollution in the City of Trabzon, Turkey. Bull. Environ. Contam. Toxicol. 77:838--845. 